2

WSRC-RP-93-580

\title{
RADIOLOGICAL IMPACT OF 1992 OPERATIONS AT THE SAVANNAH RIVER SITE
}

David M. Hamby

Westinghouse Savannah River Company Savannah River Technology Center Aiken, South Carolina 29808

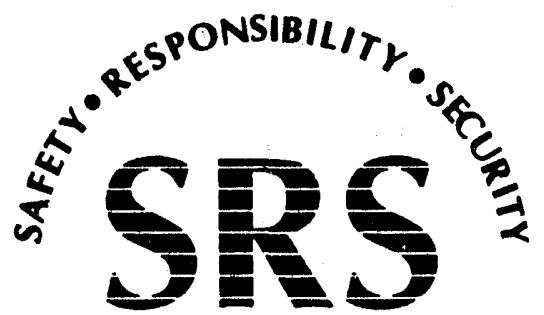

SAVANNAH RIVER SITE

Prepared for the U.S. Department of Energy under Contract No. DE-AC09-89SR18035 


\section{DISCLAIMER}

This report was prepared as an account of work sponsored by an agency of the United States Government. Neither the United States Government nor any agency thereof, nor any of their employees, makes any warranty, express or implied, or assumes any legal liability or responsibility for the accuracy, completeness, or usefulness of any information, apparatus, product, or process disclosed, or represents that its use would not infringe privately owned rights. Reference herein to any specific commercial product, process, or service by trade name, trademark, manufacturer, or otherwise does not necessarily constitute or imply its endorsement, recommendation, or favoring by the United States Government or any agency thereof. The views and opinions of authors expressed herein do not necessarily state or reflect those of the United States Government or any agency thereof.

This report has been reproduced directly from the best available copy.

Available to DOE and DOE contractors from the Office of Scientific and Technical Information, P. O. Box 62, Oak Ridge. TN 37831; prices available from (615) $576-8401$.

Available to the public from the National Technical Information Service, U. S. Department of Commerce, 5285 Port Royal Rd., Springfield, VA 22161 


\title{
Radiological Impact of 1992 Operations at the Savannah River Site
}

\author{
D.M. Hamby \\ Westinghouse Savannah River Company \\ Savannah River Site \\ Aiken, SC 29808
}

\section{Executive Summary}

The offsite individual residing at the SRS boundary location of maximum exposure (maximum individual) received a dose from SRS atmospheric releases in 1992 of $0.10 \mathrm{mrem}$. Tritium oxide releases were responsible for more than $90 \%$ of the atmospheric dose. Ninety-nine percent of the atmospheric dose is accounted for with the inclusion of $\mathrm{I}-129, \mathrm{U}-235, \mathrm{Pu}-238$ and Pu-239. The 50-mile population received a collective dose of 6.4 person-rem from 1992 releases. Ninety-nine percent of this dose also resulted from the release of the same isotopes. For both the individual and the population, atmospheric radiation dose is dominated by the inhalation and vegetation consumption pathways.

The maximum dose received by an offsite individual as a result of SRS liquid releases in 1992 was $0.13 \mathrm{mrem}$. This dose is dominated by Cs-137 that is accumulated in Savannah River fish and tritium in drinking water. More than $99 \%$ of the maximum individual dose from liquid releases results from $\mathrm{Cs}-137$, tritium, $\mathrm{Sr}-90$, and Pu-239. The population dose from liquid releases in 1992 was 2.5 person-rem. Again, tritium, Sr-90, Pu-239, and Cs-137 contributed to more than $99 \%$ of this dose. The major exposure pathway to the population is drinking water.

Radiation dose to the general public from operations at the Savannah River Site continues to be a very small fraction of the natural background dose. A resident of the CSRA receives about 300 mrem per year from background radiation. The population within 50-miles of the SRS $(620,000)$ and at the downstream water treatment facilities $(65,000)$, therefore, reccives a natural background population dose of approximatcly 200,000 person-rem.

Table 1. Five-Ycar History of Offsite Dose from SRS Operations

\begin{tabular}{|l|c|c|c|c|c|}
\hline & 1988 & 1989 & 1990 & 1991 & 1992 \\
\hline Atmospheric Releases & & & & & \\
Max. Individual (mrem) & 0.46 & 0.31 & 0.16 & 0.14 & 0.10 \\
Population (person-rem) & 21 & 17 & 9.6 & 7.1 & 6.4 \\
\hline Liquid Releases & & & & & \\
Max. Individual (mrem) & & & & & \\
Mlax. Ind. Beaufort-Jasper & 0.79 & 0.30 & 0.17 & 0.34 & 0.13 \\
Max. Ind. Port Wentworth & 0.13 & 0.12 & 0.061 & 0.081 & 0.070 \\
Population (person-rem) & 0.12 & 0.12 & 0.074 & 0.099 & 0.087 \\
& 6.2 & 4.8 & 2.3 & 3.2 & 2.5 \\
\hline
\end{tabular}




\section{Atmospheric Releases}

Releases of tritium, C-14 and I-129 to the atmosphere from tacilities at the Savannah River Site were, again, lower in 1992 than in recent years. Releases of Kr-85, I-131, and I-133, however, increased from already low amounts in 1991 with negligible impact on offsite dose. Table 2 shows the atmospheric releases by nuclide and facility.

Total tritium releases to the atmosphere were 156,000 curies for 1992. Annual tritium releases to the atmosphere over the past 10 years are given in Figure 1. Since 1985 tritium forms monitoring has enabled the Site to report release amounts for both oxide and elemental tritium releases. The larger oxide release in 1985 resulted from the leakage and evaporation of C-Reactor moderator. Figure 2 presents the 1992 atmospheric tritium rcleases by facility and chemical form. The dese to the populations exposed to atmospheric tritium is dependent upon the amount relcased as tritium oxide; tritium in the elemental form is biologically inactive. The separations facilities (all of $\mathrm{F}$ and $\mathrm{H}$ Areas) were responsible for $70 \%$ of atmospheric tritium releases and more than half of the tritium oxide released. Tritium from the reactors accounted for about $30 \%$ of tritium released to the atmosphere, less than $0.1 \%$ of which was elemental tritium. Normally, during reactor operations, reactors and separations release about equal amounts of tritium. Therefore, during reactor shutdown, the greater percentage of tritium releases shifts to the separations areas.

Figure 1. 10-Year History of Atmospheric Tritium Releases.

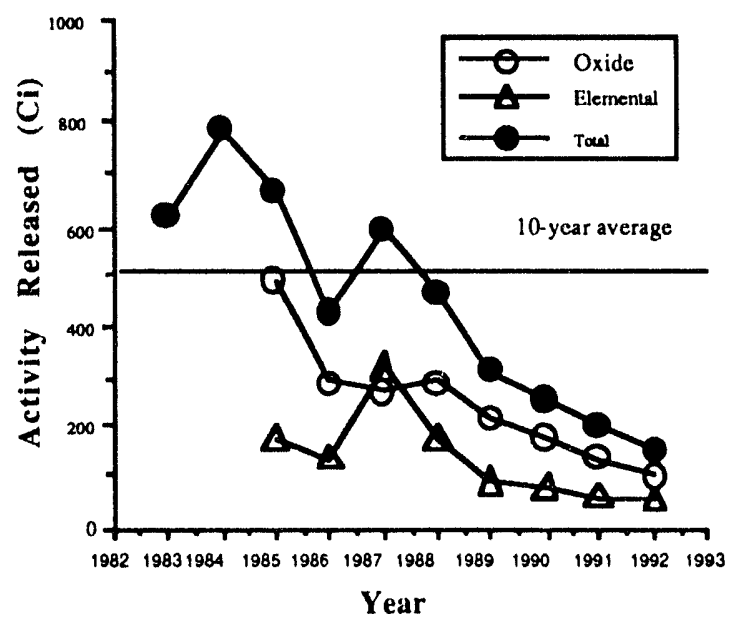

Figure 2. Relative Contribution to Atomspheric Tritium by Facility.

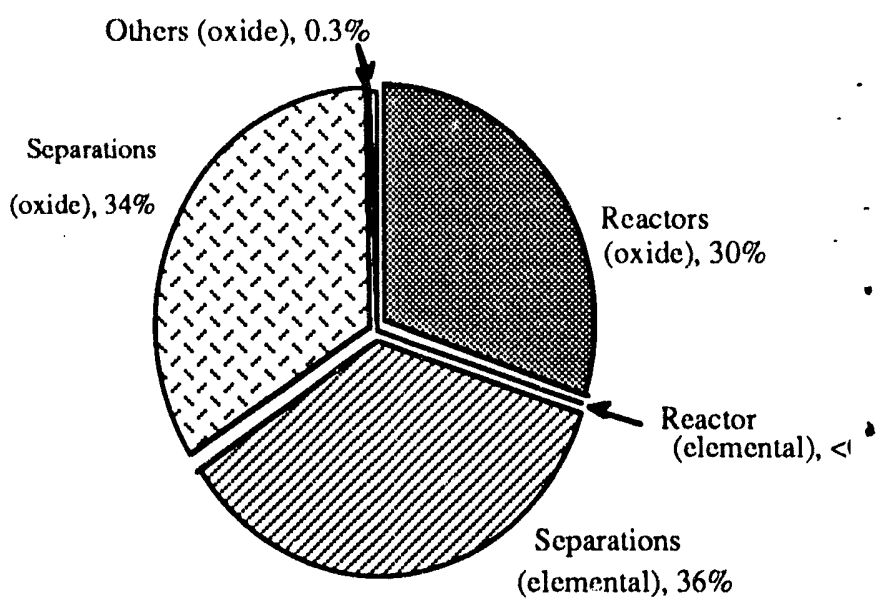

In $1992,186 \mathrm{mCi}$ of $\mathrm{C}-14$ were released from the reactors and scparations facilities accounting for less than $0.1 \%$ of the atmospheric dose to the maximum individual. The ten-year trend of C-14 atmospheric releases from SRS is shown in Figure 3. Operations at $\mathrm{K}$ Reactor resulted in the majority (98\%) of C-14 released to the atmosphere in 1992. Reduced separations processing after 1989 has resulted in the reduction of $\mathrm{C}-14$ releases to the atmosphere from the separations facilitics.

The ten-year trend for iodine-129 atmopsheric relcases are given in Figure 4. Relcases of iodine129 originate at the separations facilities and are independent of reactor status. The amount of I-129

Figure 3. 10. Year History of Atmospheric C-14 Releases.

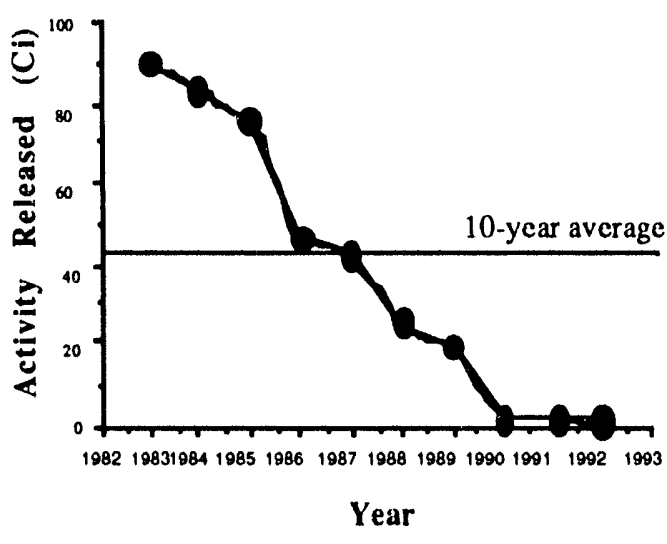


Figure 4. 10-Year History of Atmospheric I-129 Releases.

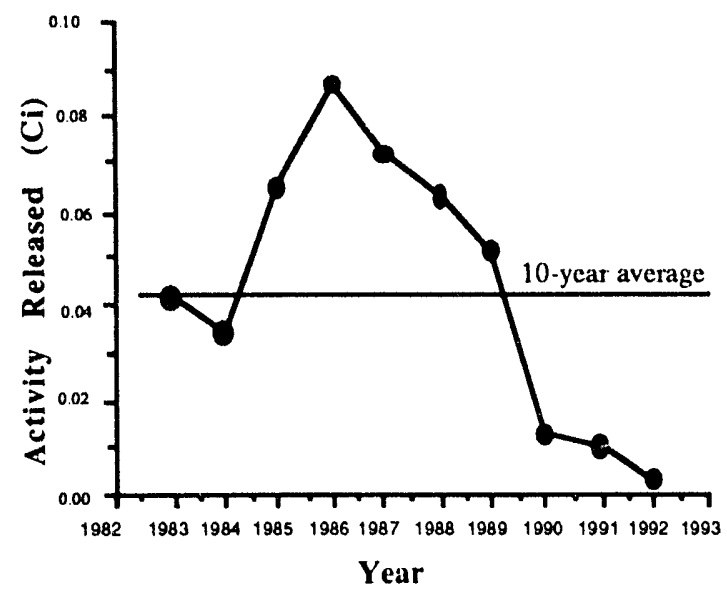

released has decreased from 1991. Iodine-131 relcases are normally the result of reactor operations and were therefore very low during 1992.

Figure 5 shows that relcase amounts of Sr-90 have decreased compared to 1991 releases, whereas detected amounts of Pu-238 and Pu-239 are slightly above 1991 values. More than $90 \%$ of the atmospheric Pu-239 relcases were from the scparations facilitics. As noted in Table 2, unidentified alpha activity relcased to the atmosphere is assumed to bc Pu-239 and unidentified beta is assumed to be Sr-90. These assumptions are made to ensure conservative dose estimates. Approximately $50 \%$ of the total Pu-239 and $90 \%$ of the total Sr-90 (including aqueous relcases) is unidentificd alpha and beta-gamma, respectively.

Figure 6. 10-Year History of Atmospheric Noble Gas Releases

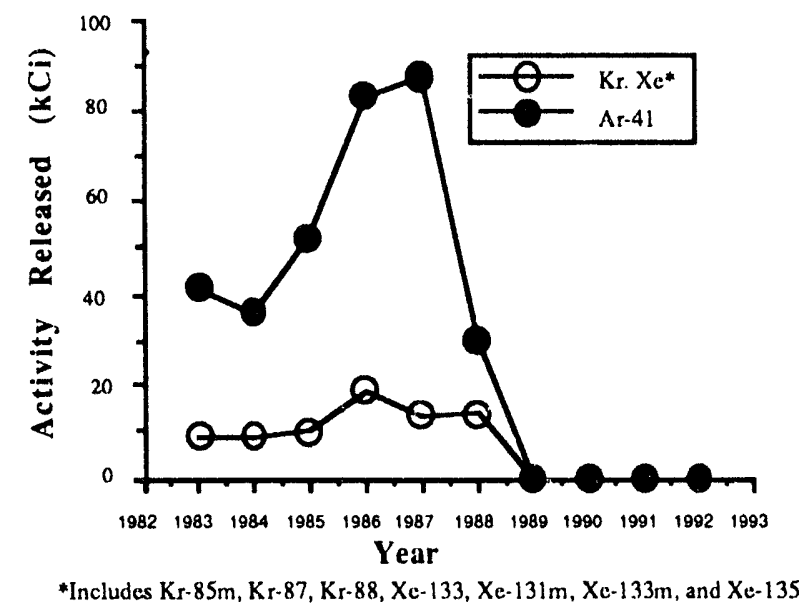

Figure 5. 10-Year History of Atmospheric Sr-90, Pu-238, and Pu-239

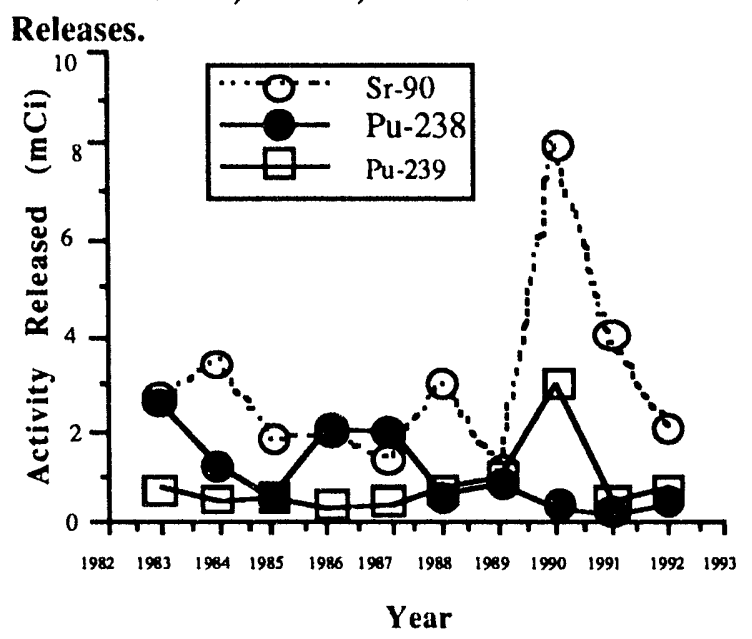

Figure 6 shows the ten-year trend of short-lived noble gascs (Kr-85 not included) released at the SRS. Since the release of these gases is entircly dependent upon reactor operations, only a very small amount of Ar-41 was relcased due to K-Reactor operations, otherwise no short-lived noble gases have been released since 1988 . K Reactor was operational during only a short time in 1992.

Sources of fugitive radiological $\mathrm{cmissions}$ to the atmosphere were included in the source term for the first time in 1991. These sources are included in the annual NESHAP report and the Annual Environmental Report. As seen in Table 2, a few nuclides are included in the source term for fugitive emissions only: Zr-95, Sb-125, Eu-154, and Eu-155. Doses resulting from atmospheric releases are not significantly $i$ luenced by the addition of these fugitive sourci.. 
Table 2. 1992 Atmospheric Releases (curies)

\begin{tabular}{|c|c|c|c|c|c|c|c|}
\hline Nuclide & Reactors & Sepns & Raw. Mat & H. Water & SRTC & $\begin{array}{l}\text { Fugitive } \\
\text { (a) }\end{array}$ & Total \\
\hline \multicolumn{8}{|c|}{ GASES AND VAPORS } \\
\hline H-3 (oxide) & $4.67 \times 10^{4}$ & $5.31 \times 10^{4}$ & & $4.82 \times 10^{2}$ & & $7.83 \times 10^{0}$ & $1.00 \times 10^{5}$ \\
\hline $\mathrm{H}-3(\mathrm{elem})$ & $6.59 \times 10^{1}$ & $5.58 \times 10^{4}$ & & & & & $5.59 \times 10^{4}$ \\
\hline H-3(total) & $4.68 \times 10^{4}$ & $1.09 \times 10^{5}$ & & $4.82 \times 10^{2}$ & & $7.83 \times 10^{0}$ & $1.56 \times 10^{5}$ \\
\hline C-14 & $1.83 \times 10^{-1}$ & $3.08 \times 10^{-3}$ & & & & & $1.86 \times 10.1$ \\
\hline $\mathrm{Ar}-41$ & $2.51 \times 10^{2}$ & & & & & & $2.51 \times 10^{2}$ \\
\hline $\mathrm{Kr}-85$ & $4.99 \times 10^{1}$ & & & & & & $4.99 \times 10^{1}$ \\
\hline $\mathrm{Xe}-135$ & & & & & $2.43 \times 10^{-3}$ & & $2.43 \times 10^{-3}$ \\
\hline $\mathrm{I}-129$ & & $3.50 \times 10^{-3}$ & & & & & $3.50 \times 10^{-3}$ \\
\hline $\mathrm{I}-131$ & $1.42 \times 10^{-6}$ & $4.10 \times 10^{-5}$ & & & $5.75 \times 10^{-5}$ & & $9.99 \times 10^{-5}$ \\
\hline $\mathrm{I}-133$ & & & & & $1.15 \times 10^{-3}$ & & $1.15 \times 10^{-3}$ \\
\hline $\mathrm{I}-135$ & & & & & $1.34 \times 10^{-1}$ & & $1.34 \times 10^{-1}$ \\
\hline \multicolumn{8}{|c|}{ PARTICULATES } \\
\hline Co-60 & & $3.60 \times 10^{-7}$ & & & & $3.34 \times 10^{-17}$ & $3.60 \times 10^{7}$ \\
\hline $\mathrm{Sr}-89,90(\mathrm{~b})$ & $2.37 \times 10^{-4}$ & $1.62 \times 10^{-3}$ & $2.24 \times 10^{-5}$ & $1.41 \times 10^{-5}$ & $3.02 \times 10^{-5}$ & $1.13 \times 10^{4}$ & $2.03 \times 10^{-3}$ \\
\hline $\mathrm{Zr}-95$ & & & & & & $2.39 \times 10^{-14}$ & $2.39 \times 10^{-14}$ \\
\hline $\mathrm{Ru}-106$ & & $1.81 \times 10^{-6}$ & & & & $4.96 \times 10^{-12}$ & $1.81 \times 10^{-6}$ \\
\hline $\mathrm{Sb}-125$ & & & & & & $7.27 \times 10^{-15}$ & $7.27 \times 10^{-15}$ \\
\hline Cs-134 & & $3.75 \times 10^{-8}$ & & & & $1.40 \times 10^{-17}$ & $3.75 \times 10^{.8}$ \\
\hline Cs-137 & $3.05 \times 10^{-5}$ & $2.16 \times 10^{-4}$ & & & $3.94 \times 10^{-6}$ & $4.33 \times 10^{-11}$ & $2.50 \times 10^{-4}$ \\
\hline Ce-144 & & $1.16 \times 10^{-7}$ & & & & $1.13 \times 10^{-13}$ & $1.16 \times 10^{-7}$ \\
\hline Eu-154 & & - & & & & $3.44 \times 10^{-13}$ & $3.44 \times 10^{-13}$ \\
\hline $\mathrm{Eu}-155$ & & 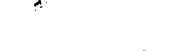 & & & & $1.63 \times 10^{-13}$ & $1.63 \times 10^{-13}$ \\
\hline U-235,238 & & $1.52 \times 10^{-3}$ & $5.12 \times 10^{-6}$ & & & $5.74 \times 10^{-5}$ & $1.58 \times 10^{-3}$ \\
\hline Pu-238 & & $4.42 \times 10^{-4}$ & & & & $4.00 \times 10^{-6}$ & $4.46 \times 10^{-4}$ \\
\hline $\mathrm{Pu}-239(\mathrm{c})$ & $6.77 \times 10^{-9}$ & $6.86 \times 10^{-4}$ & $3.22 \times 10^{-6}$ & $5.27 \times 10^{-7}$ & $5.46 \times 10^{-5}$ & $5.01 \times 10^{-7}$ & $7.45 \times 10^{-4}$ \\
\hline $\begin{array}{l}\text { Am- } \\
241,243\end{array}$ & & $1.13 \times 10^{-4}$ & & & $2.34 \times 10^{-8}$ & $8.86 \times 10^{-13}$ & $1.13 \times 10^{-4}$ \\
\hline $\begin{array}{l}\mathrm{Cm}- \\
242,244\end{array}$ & & $2.30 \times 10^{-5}$ & & & $7.90 \times 10^{-8}$ & $7.33 \times 10^{-12}$ & $2.31 \times 10^{-5}$ \\
\hline
\end{tabular}

(a) Estimated releases from minor unmonitored diffuse and fugitive sources.

(b) Includes unidentified beta-gamma.

(c) Includes unidentified alpha. 


\section{Liquid Releases}

Aqueous radioactive relcases for 1992 are given in Table 3. Like atmospheric releases, liquid discharge rates were generally lower than in 1991 except for Sr90 and Cs-137. Tritium, strontium-90, cesium-137, and plutonium-239 are responsible for more than $99 \%$ of the maximum individual and population doses from liquid relcases.

During the latter part of December 1991, approximately 5700 curies of tritium were released from one of the K-Reactor heat exchangers. Dose to the offsite population as a result of that release was included in the annual dose calculations for 1991.

In 1992, approximately $83 \%$ of the total tritium reaching the Savannah River originated from seepage basin migration with the remainder coming from direct releases to onsite streams. The release values given in Table 3 and subsequent figures include tritium from both direct relcases and seepage basin migration. The ten-year trend of tritium reaching the Savannah River is given in Figure 7. As seen in the figure, the 1992 release is considerably lower than the 1991 release. The increase in the curve during 1991 is due to the December release from the K-Reactor heat exchanger.
Annual average tritium concentrations at various locations along the Savannah River are presented in Figure 8. Concentrations at sampling locations above the Site (River 2), just below the Site (River 10) and 100 miles downstream, at Beaufort-Japser and Port Wentworth are shown. The average tritium concentration in the river just below the SRS was about 8 times higher than the average upstream concentration. The values presented for the BeaufortJasper and Port Wentworth areas are the concentrations measured in finished drinking water at each facility. Over the past 10 years, annual average tritium concentrations in the drinking water at Beaufort-Jasper and Port Wentworth have been less than $17 \%$ of the EPA guide for public drinking water supplies of $20 \mathrm{pCi} / \mathrm{mL}$. In 1992, tritium concentrations in the drinking water supplies were less than $8 \%$ of the EPA guide. (The EPA is proposing that the annual average tritium concentration in drinking water guide be increased to $60.9 \mathrm{pCi} / \mathrm{mL}$.)

Beaufort-Jasper and Port Wentworth are the only two public water systems that draw water directly from the Savannah River at locations downstream of the SRS. At distances of 100 miles downstream it is expected that water from the two systems would have essentially the same tritium concentrations. Except for small variations, this is shown to be the case

Table 3. 1992 Liquid Releases (curies)

\begin{tabular}{|c|c|c|c|c|c|c|}
\hline Nuclide & Reactors & Sepns & Raw. Mat & H. Water & SRTC & Total \\
\hline $\mathrm{H}-3^{*}$ & $2.30 \times 10^{3}$ & $1.09 \times 10^{4}$ & & $5.67 \times 10^{2}$ & $3.67 \times 10^{-1}$ & $1.38 \times 10^{4}$ \\
\hline Sr-90 (a) & $4.21 \times 10^{-1}$ & $3.07 \times 10^{-1}$ & $9.24 \times 10^{-4}$ & $5.28 \times 10^{-2}$ & $3.94 \times 10^{-3}$ & $7.86 \times 10^{-1}$ \\
\hline I-129 & & $2.20 \times 10^{-2}$ & & & & $2.20 \times 10^{-2}$ \\
\hline Cs-137 & & $1.01 \times 10^{-1}$ & & & & $1.01 \times 10^{-1}$ \\
\hline $\mathrm{Pm}-147$ & & $2.45 \times 10^{-4}$ & & & & $2.45 \times 10-4$ \\
\hline U-235,238 & & $1.31 \times 10^{-5}$ & $1.89 \times 10^{-3}$ & & & $1.90 \times 10^{-3}$ \\
\hline $\mathrm{Pu}-239$ (b) & $7.70 \times 10^{-3}$ & $7.44 \times 10^{-3}$ & $4.60 \times 10^{-4}$ & & $5.02 \times 10^{-4}$ & $1.61 \times 10^{-2}$ \\
\hline
\end{tabular}

* includes direct releases and seepage basin migration.

Note: Unidentified alpha releases included as Pu-239 and nonvolatile beta included at Sr-90. 
Figure 7. 10-Year History of Aqueous Tritium Releases.

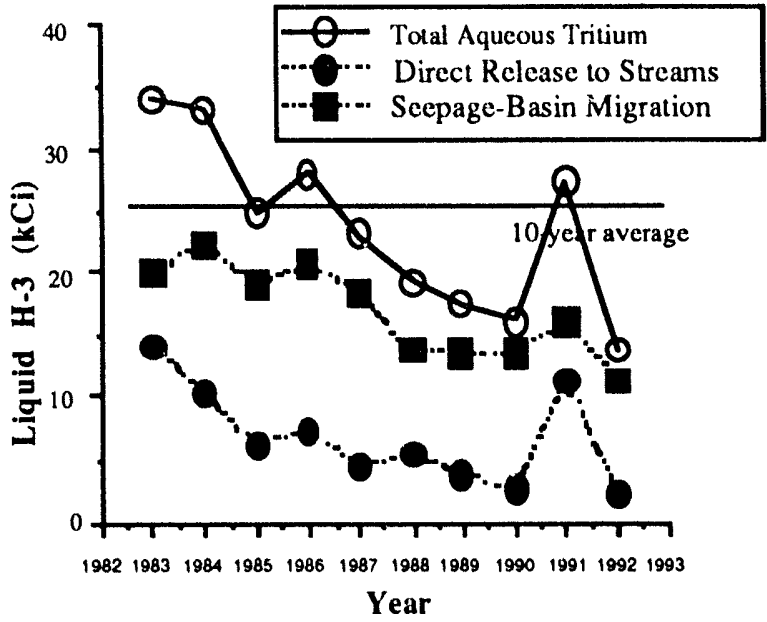

since 1985. Prior to that time, the Beaufort-Jasper water treatment facility drew its water via a canal to the Savannah River that crossed the floodplain and was diluted by inland surface water. Due to water treatment plant processing problems with high levels of organic compounds and low levels of suspended solids in the surface water, the canal was modified in June of 1985 to prevent the entrainment of inland surface water into the intake station, thereby eliminating the dilution of the intake water.

Aqueous release amounts of Sr-90, Cs-137, and Pu-239 are given in Figure 9 for the 10-year period, 1983 through 1992. Strontium-90 (including unidentified beta/gamma) releases have been increasing since 1989 as a result of several different processes. Scepage basin migration of $\mathrm{Sr}-90$ into onsite streams resulted in higher releases in 1991 and

Figure 9. 10-Year History of Aqueous Sr-90, Cs-137, and Pu-239 Releases.

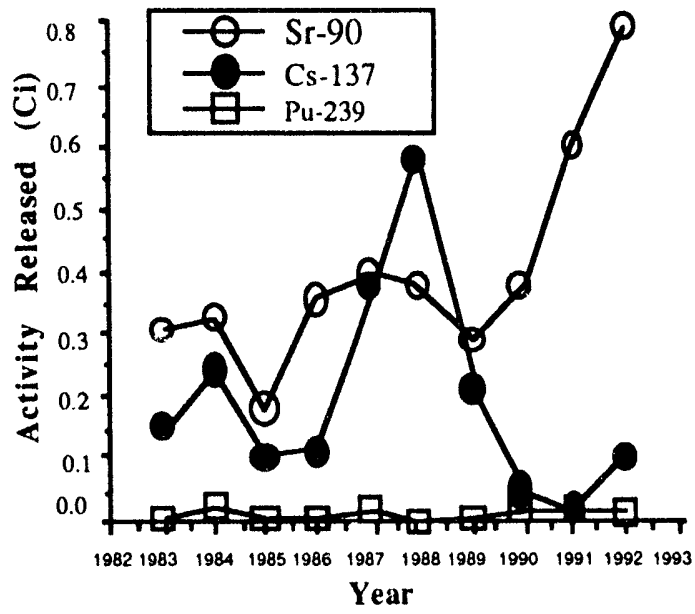

Figure 8. Tritium Concentrations in the Savannah River

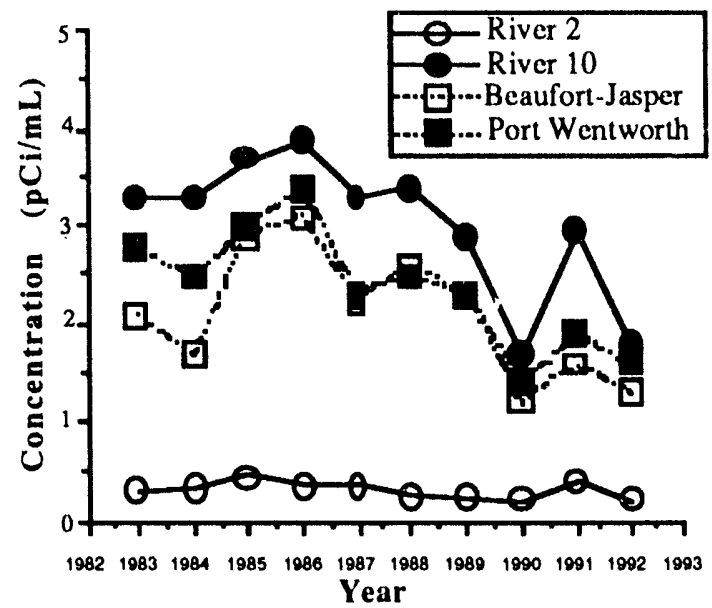

1992. Routine Sr-90 releases from facilities, however, continue to decrease. One sample from the $\mathrm{K}$-Reactor discharge canal resulted in higher than normal relcase levels of unidentified beta-gamma

This, however, was not confirmed and operations during that time indicated that the result was erroneous. This questionable sample has been included in the 1992 source tcrm. In 1992, aqueous releases of Cs-137 have increased over 1991. Aqueous plutonium (including unidentified alpha) releases have essentially remained the same over the past several years. The apparent peak of aqueous Cs-137 releases during 1987and 1988 results from changes in analytical methods and detection sensitivities. Figure 10 provides annual average Cs-137 concentrations in Savannah River water measured both upstream (River 2) and downstream (River 10) of the SRS.

Figure 10. Cs-137 Concentrations in the Savannah River.

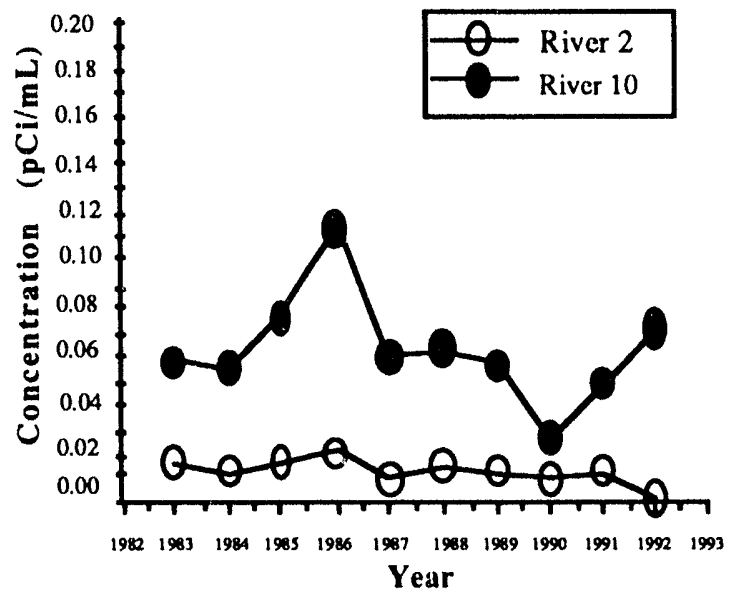


Figure 11A. Aqueous Releases by Facility (Sr-90).

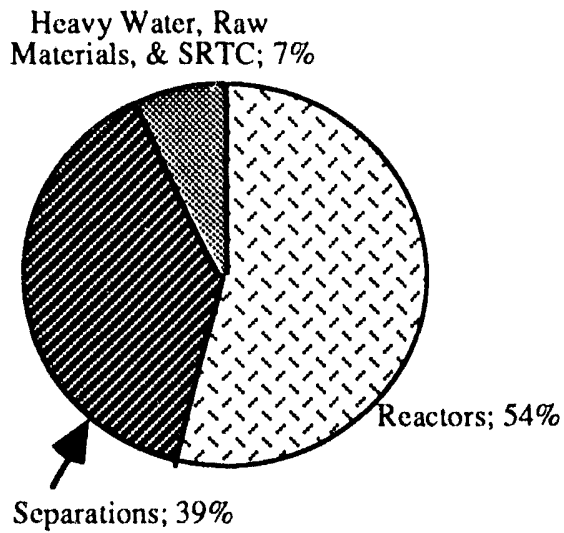

In 1992, all aqueous Cs-137 releases were from the separations facilitics. As secn in Figures $11 \mathrm{~A}$ and $11 \mathrm{~B}$, the dominant releases of aqueous Sr-90 and $\mathrm{Pu}-239$ are from the reactors and separations facilities. Other facilities release only about $7 \%$ of the total Sr-90 and $6 \%$ of the total Pu-239 released to to surface water

\section{Atmospheric Dose}

Atmospheric dose estimates are calculated using derivatives of the NRC computer programs XOQDOQ and GASPAR. SRTC's versions of these atmospheric transport and dosimetry codes, MAXIGASP and POPGASP, provide dose predictions for an average individual, a maximum individual, and the population within $80 \mathrm{~km}(50$ miles) of the geographic center of the SRS. Individual doses are calculated for hypothetical persons living at the boundary of the reservation for the entire year.

Average individual dose at the Savannah River Site continues to decrease. Doses are given by pathway and radionuclide in Table $\Delta$ The critical pathways through which the average individual at the plant boundary receives the majority of his/her dose are inhalation and the consumption of vegetation grown at the Site boundary. The nuclides of major importance are shown to be tritium, I-129, $\mathrm{U}-235 / 238$, and Pu-238/239. The dose to the hypothetical average individual living at the site boundary from site opcrations in 1992 was 0.040 mrem.

Table 5 presents the dose estimates for the maximum individual at the site boundary. The dose by pathway again shows that the inhalation pathway contributes more to total dose than the consumption of
Figure 11B. Aqueous Releases by Facility (Pu-239)

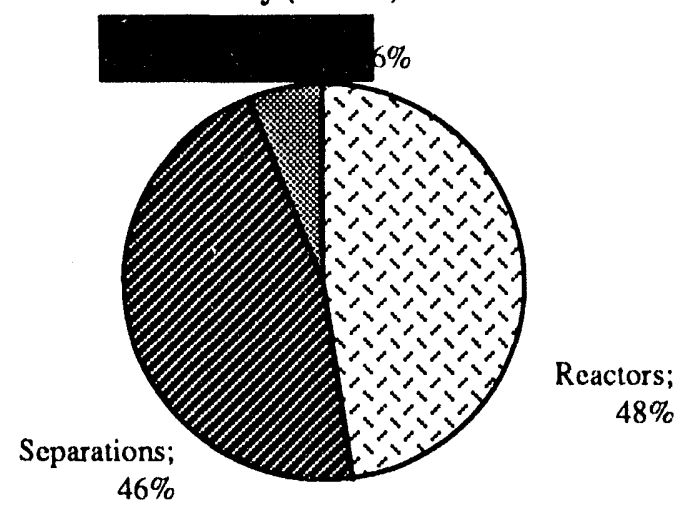

vegetation. The milk pathway contributes about 16 percentage points more to maximum dose than it does to average dose. This is a result of milk consumption dose being based on the consumption of goat's milk for the maximum individual and cow's milk for the average individual. The biokinetics controling radionuclide uptake and retention by goats is such that goat's milk contains higher nuclide concentrations resulting in higher doses per unit volume of milk consumed. The nuclides of interest for the maximum individual are, again, tritium, I-129, U-235/238, and $\mathrm{Pu}-238 / 239$. The maximum individual's dose resulting from the 1992 atmospheric releases was estimated to be $0.10 \mathrm{mrem}$, lower than in 1991 .

The estimate of cumulative dose to the population within $80 \mathrm{~km}$ of the SRS for 1992 is shown in Table 6 . A breakdown of the estimate by pathway and nuclide is presented in the table and graphically in Figures 12A and 12B. Again, the critical pathways for the population are inhalation and the consumption of vegetation. As expected, the critical nuclides are tritium, I-129, U-235/238, and $\mathrm{Pu}-238 / 239$. The population dose from atmospheric releases in 1992 from SRS operations was estimated to be 6.4 personrem.

The trends of average and maximum individual doses over the past 10 years are given in Figure 13. The dose estimates for 1992 are lower than any other in the ten-year period. The ten-year trend of population doses is given in Figure 14. The data show that individual and population doses have been steadily decreasing since 1987.

Tables 7 and 8 provide breakdowns of maximum individual and population dose by nuclide and release facility. These tables are tiseful in determining relative and absolute contributions from facilities and/or nuclides to the offsite dose via atmospheric pathways. 
Table 5. Maximum Individual Dose ${ }^{\mathrm{a}}$ Commitment at Plant Perimeter from Atmospheric Releases

\section{BY PATHWAY}

\begin{tabular}{lll} 
Pathway & $\begin{array}{l}\text { Max. Individual } \\
\text { Dose (mrem) }\end{array}$ & $\begin{array}{l}\text { Pcrcent of } \\
\text { Total Dose }\end{array}$ \\
\hline Inhalation & $4.2 \times 10^{-2}$ & 41.2 \\
Vegetation & $3.0 \times 10^{-2}$ & 29.9 \\
Milk & $2.5 \times 10^{-2}$ & 24.1 \\
Meat & $4.5 \times 10^{-3}$ & 4.4 \\
Plume & $3.3 \times 10^{-4}$ & 0.3 \\
Ground & $1.2 \times 10^{-4}$ & 0.1 \\
& & \\
Total & $1.0 \times 10^{-1}$ & \\
& & \\
BY RADIONUCLIDE & & Percent of \\
Radionuclide & Max. Individual & Total Dose \\
\hline Gases \& Vapors & Dose (mrem) & \\
H-3 & & 90.5 \\
C-14 & $9.2 \times 10^{-2}$ & $<0.1$ \\
Ar-41 & $6.7 \times 10^{-5}$ & 0.3 \\
Kr-85 & $3.3 \times 10^{-4}$ & $<0.1$ \\
I-129 & $1.9 \times 10^{-7}$ & 2.0 \\
I-131 & $2.0 \times 10^{-3}$ & $<0.1$ \\
Particulates & $4.3 \times 10^{-8}$ & \\
Sr-90 & & 0.1 \\
Ru-106 & $1.3 \times 10^{-4}$ & $<0.1$ \\
Cs-134,137 & $4.8 \times 10^{-8}$ & $<0.1$ \\
U-235,238 & $3.4 \times 10^{-5}$ & 0.9 \\
Pu-238 & $9.3 \times 10^{-4}$ & 1.3 \\
Pu-239 & $1.3 \times 10^{-3}$ & 4.4 \\
Am-241,243 & $4.4 \times 10^{-3}$ & 0.4 \\
Cm-242,244 & $3.8 \times 10^{-4}$ & $<0.1$ \\
Total & $4.1 \times 10^{-5}$ & \\
\hline & $1.0 \times 10^{-1}$ & \\
\hline & & \\
\hline
\end{tabular}

* Individual resides at the site boundary and consumes maximum amounts of food (includes goat's milk). Committed effective dose equivalent is reported. 
Table 6. 50-Mile Population Dose Commitment at ${ }^{\text {at }}$ Plant Perimeter from Atmospheric Releases

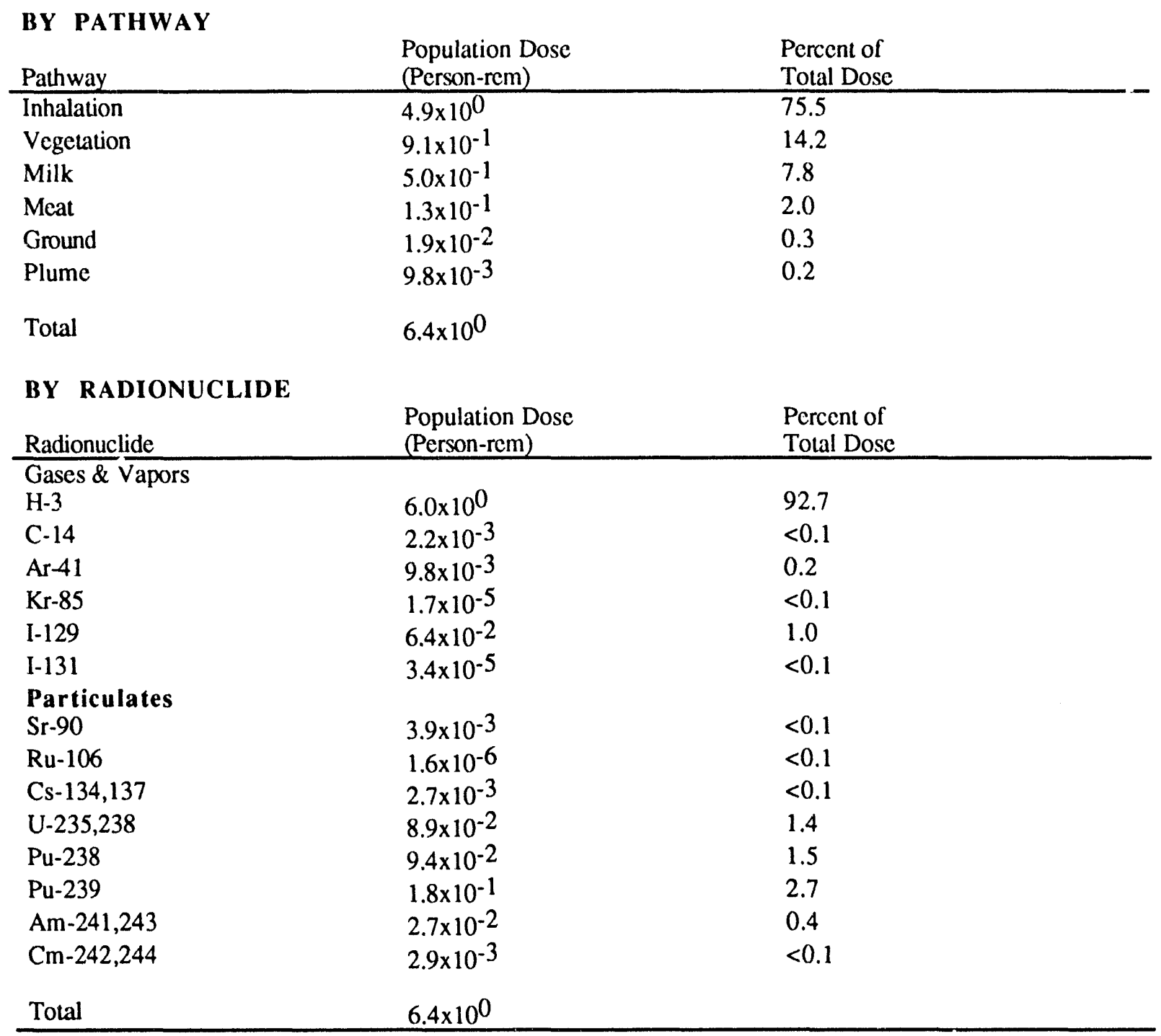

a. Committed effective dose equivalent is reported (cows milk). 
Figure 12A. Population Dose from Atmospheric Releases.

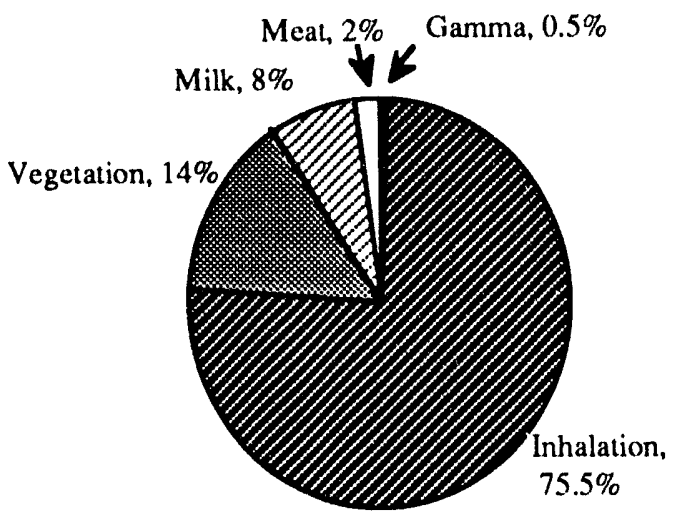

Figure 13. 10-Year History of Individual

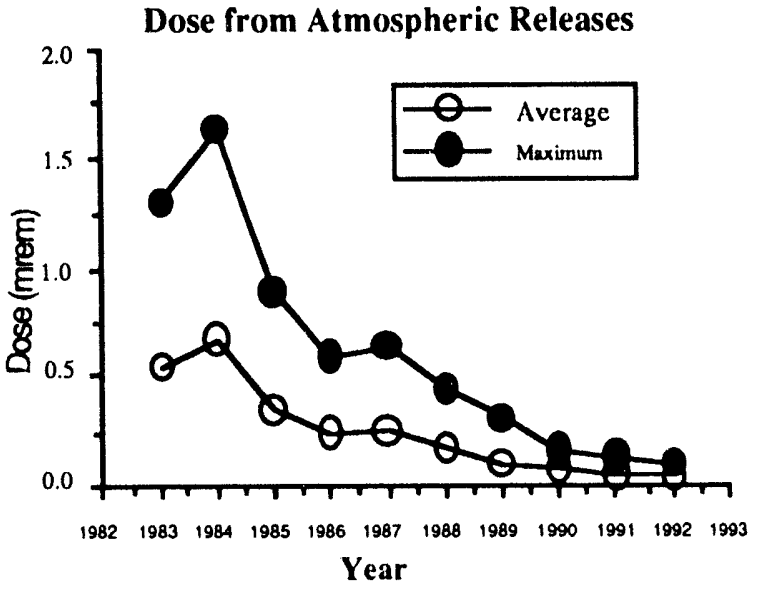

Figure 12B. Population Dose from Atmospheric Releases.

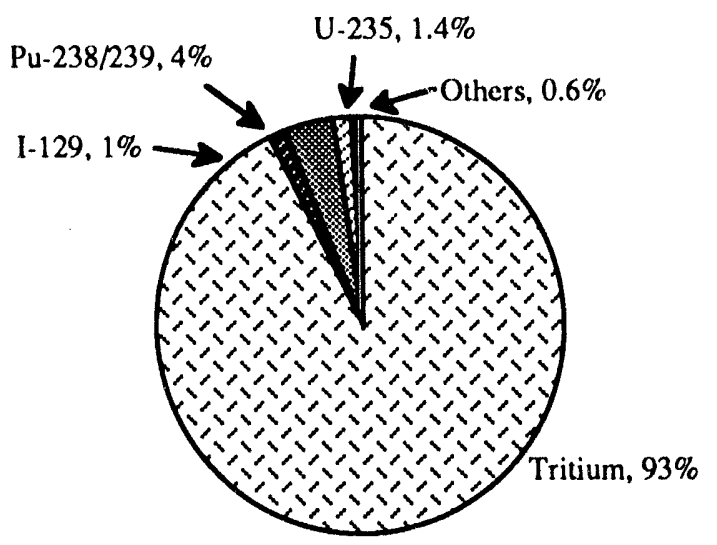

Figure 14. 10-Year History of Population Dose from Atmospheric Releases

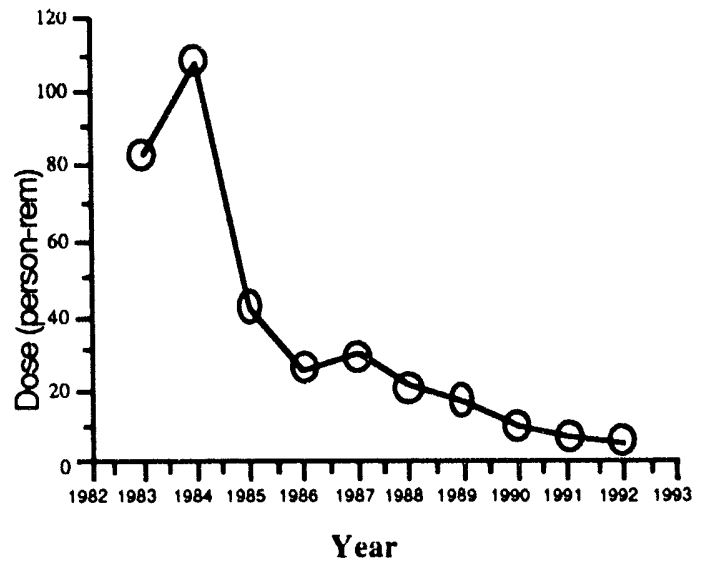




\section{Liquid Doses}

The maximum individual dose is estimated for a hypothetical individual that drinks ordinary amounts of untreated river water, consumes large amounts of fish, and spends many hours swimming, fishing, and beating on the Savannah River. This dose is estimated using LADTAP II, an NRC code for determining dose to man from liquid effluents. Table 9 gives the breakdown of the maximum individual's dose by pathway and radionuclide for liquid releases.

Strontium-90 and Cs-137 accumulation in fish and tritium in river water used for consumption account for about $90 \%$ of the maximum individual's dose. The dose to the maximum individual resulting from aqueous releases during 1992 was $0.13 \mathrm{mrcm}$.

The maximum dose to individuals consuming water processed by the Bcaufort-Jasper and Port Wentworth water treatment facilities is calculated assuming a consumption rate of 2 liters per day. The maximum individual's on these domestic water systems reccived doses of $0.070 \mathrm{mrem}$ (Bcaufort-Jasper) and $0.087 \mathrm{mrem}$ (Port Wentworth).

The population dose is calculated for several population groups. One group uses the Savannah River for recreational purposes, one group consumes sport and commercial fish and one group drinks treated river water from the Beaufort-Jasper or Port Wentworth public water systems. Table 10 presents the population dose to Savannah River users by pathway (population group) and by radionuclide.

Figure 15A. Population Dose from Liquid Releases.

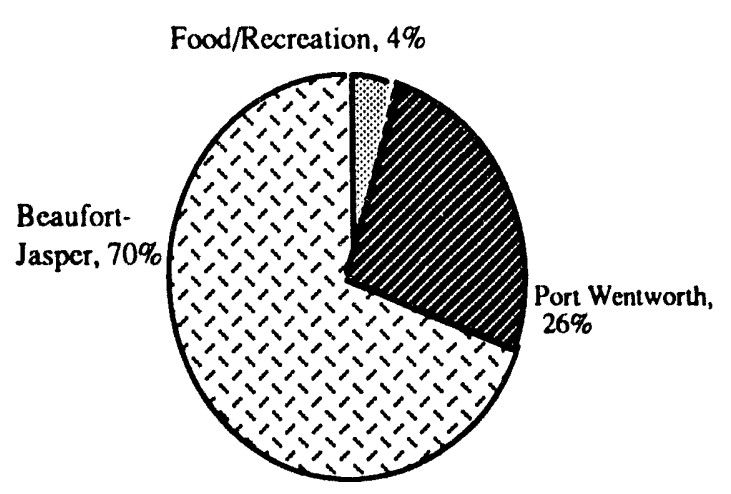

More than $95 \%$ of the population dose can be attributed to the drinking water supplies at BeaufortJasper and Port Wentworth. Tritium, Sr-90, Cs-137 and $\mathrm{Pu}-239$ are responsible for more than $99 \%$ of the population dose from aqueous releases. (For the purposes of conservatively estimating dose, all unidentified beta/gamma activity is assumed to be Sr-90 and all unidentified alpha activity is assumed to be $\mathrm{Pu}-239$.) Tritium and $\mathrm{Pu}-239$ deliver the water ingestion dose while Sr-90 and Cs-137 deliver the fish consumption dose. Figures 15A and 15B show the pathway and nuclide breakdowns for the population dose. The total population dose from liquid releases in 1992 was 2.5 person-rem.

Figures 16 and 17 present the ten-year trends of maximum individual and population dose estimates for liquid effluents to the Savannah River. The maximum individual dose trend shows a decrease in the 1992 dose estimate from 1991. This is attributed to the dose increase in 1991 resulting from tritium released during the K-Reactor incident in late December of that year. Dose to the maximum individual in $: 992$ is the lowest within the past 10 ycars.

Since the population dose is dominated by tritium in drinking water, the dose trend is consistent with tritium release amounts and concentrations downstream of the SRS.

Breakdowns of maximum individual and population dose by nuclide and facility are given in Tables 11 and 12 , respectivcly, for offsite doses via liquid pathways.

Figure 15B. Population Dose from Liquid Releases.

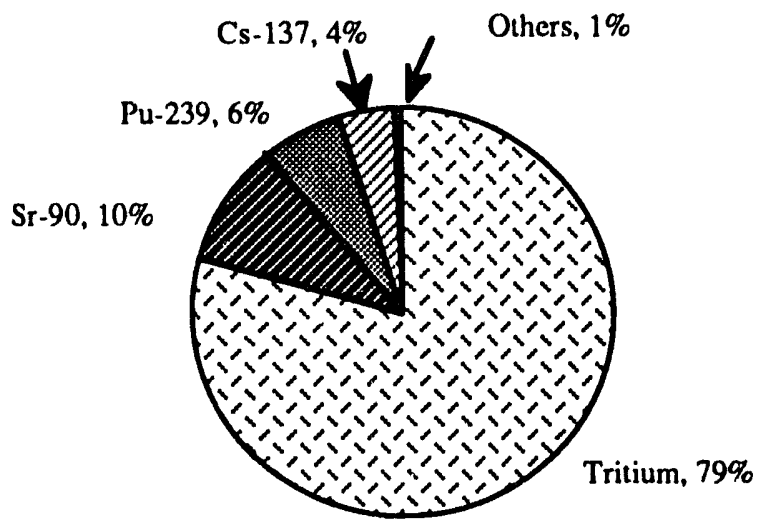


Table 7. Maximum Individual Dose (mrem) from Atmospheric Releases

\begin{tabular}{|c|c|c|c|c|c|c|c|c|}
\hline Nuclide & Reactors & Sepns & Raw Mat. & H. Water & SRL & Fugitive & Total & $\%$ of Total \\
\hline H-3 (oxide) & $4.3 \times 10^{-2}$ & $4.9 \times 10^{-2}$ & & $2.8 \times 10^{-4}$ & & $4.6 \times 10^{-6}$ & $9.2 \times 10^{-2}$ & 90.5 \\
\hline C-14 & $6.5 \times 10^{-5}$ & $1.1 \times 10^{-6}$ & & & & & $6.7 \times 10^{-5}$ & $<0.1$ \\
\hline $\operatorname{Ar}-41$ & $3.3 \times 10^{-4}$ & & & & & & $3.3 \times 10^{-4}$ & 0.3 \\
\hline Co- 60 & & $3.9 \times 10^{-8}$ & & & & $3.7 \times 10^{-18}$ & $4.0 \times 10^{-8}$ & $<0.1$ \\
\hline $\mathrm{Zn}-65$ & & & & & & & & $<0.1$ \\
\hline $\mathrm{Kr}-85$ & $1.9 \times 10^{-7}$ & & & & & & $1.9 \times 10^{-7}$ & $<0.1$ \\
\hline Sr-90 & $1.6 \times 10^{-5}$ & $1.1 \times 10^{-4}$ & $1.5 \times 10^{-6}$ & $9.3 \times 10^{-7}$ & $2.0 \times 10^{-6}$ & $7.5 \times 10^{-6}$ & $1.4 \times 10^{-4}$ & 0.1 \\
\hline Zr-95 & & & & & & $7.5 \times 10^{-17}$ & $7.5 \times 10^{-17}$ & $<0.1$ \\
\hline $\mathrm{Nb}-95$ & & & & & & & & $<0.1$ \\
\hline $\mathrm{Ru}-106$ & & $4.8 \times 10^{-8}$ & & & & $1.3 \times 10^{-13}$ & $4.8 \times 10^{-8}$ & $<0.1$ \\
\hline Sb-125 & & & & & & $8.3 \times 10^{-17}$ & $8.3 \times 10^{-17}$ & $<0.1$ \\
\hline I-129 & & $2.0 \cdot 10^{-3}$ & & & & & $2.0 \times 10^{-3}$ & 2.0 \\
\hline I-131 & $6.1 \times 10^{-8}$ & $1.8 \times 17^{-6}$ & & & $2.5 \times 10^{-6}$ & & $4.3 \times 10^{-6}$ & $<0.1$ \\
\hline $1-133$ & & & & & $1.3 \times 10^{-6}$ & & $1.3 \times 10^{-6}$ & $<0.1$ \\
\hline I-135 & & & & & $1.8 \times 10^{-5}$ & & $1.8 \times 10^{-5}$ & $<0.1$ \\
\hline $\mathrm{Xe}-135$ & & & & & $1.4 \times 10^{-8}$ & & $1.4 \times 10^{-8}$ & $<0.1$ \\
\hline Cs-134 & & $2.6 \times 10^{-9}$ & & & & $9.9 \times 10^{-19}$ & $2.7 \times 10^{-9}$ & $<0.1$ \\
\hline Cs-137 & $4.1 \times 10^{-6}$ & $2.9 \times 10^{-5}$ & & & $5.3 \times 10^{-7}$ & $5.8 \times 10^{-12}$ & $3.4 \times 10^{-5}$ & $<0.1$ \\
\hline Ce-141 & & & & & & & & $<0.1$ \\
\hline Ce-144 & & $8.3 \times 10^{-10}$ & & & & $8.1 \times 10^{-16}$ & $8.3 \times 10^{-10}$ & $<0.1$ \\
\hline Pm-147 & & & & & & & & $<0.1$ \\
\hline Eu-154 & & & & & & $3.1 \times 10^{-14}$ & $3.1 \times 10^{-14}$ & $<0.1$ \\
\hline Eu-155 & & & & & & $6.0 \times 10^{-16}$ & $6.0 \times 10^{-16}$ & $<0.1$ \\
\hline U-235 & & $9.0 \times 10^{-4}$ & $3.0 \times 10^{-6}$ & & & $3.4 \times 10^{-5}$ & $9.3 \times 10^{-4}$ & 0.9 \\
\hline $\mathrm{Pu}-238$ & & $1.3 \times 10^{-3}$ & & & & $1.2 \times 10^{-5}$ & $1.3 \times 10^{-3}$ & 1.3 \\
\hline Pu-239 & $4.0 \times 10^{-8}$ & $4.1 \times 10^{-3}$ & $1.9 \times 10^{-5}$ & $3.1 \times 10^{-6}$ & $3.2 \times 10^{-4}$ & $3.0 \times 10^{-6}$ & $4.4 \times 10^{-3}$ & 4.4 \\
\hline Am-241 & & $3.8 \times 10^{-4}$ & & & $7.8 \times 10^{-8}$ & $3.0 \times 10^{-12}$ & $3.8 \times 10^{-4}$ & 0.4 \\
\hline $\mathrm{Cm}-244$ & & $4.1 \times 10^{-5}$ & & & $1.4 \times 10^{-7}$ & $1.3 \times 10^{-11}$ & $4.1 \times 10^{-5}$ & $<0.1$ \\
\hline Dose Total & $4.3 \times 10^{-2}$ & $5.8 \times 10^{-2}$ & $2.4 \times 10^{-5}$ & $2.9 \times 10^{-4}$ & $3.5 \times 10^{-4}$ & $6.0 \times 10^{-5}$ & $1.0 \times 10^{-1}$ & \\
\hline$\%$ of Total & 42.5 & 56.6 & $<0.1$ & 0.3 & 0.3 & $<0.1$ & & \\
\hline
\end{tabular}


Table 8. Population Dose (person-rem) from Atmospheric Releases

\begin{tabular}{|c|c|c|c|c|c|c|c|c|}
\hline Nuclide & Reactors & Sepns & Raw Mat. & H. Water & SRL & Fugitive & Total & $\begin{array}{c}\% \text { of } \\
\text { Total }\end{array}$ \\
\hline H-3 (oxide) & $2.8 \times 10$ & $3.2 \times 10$ & & $2.9 \times 10^{-2}$ & & $4.6 \times 10^{-4}$ & $6.0 \times 10$ & 92.7 \\
\hline C-14 & $2.2 \times 10^{-3}$ & $3.7 \times 10^{-5}$ & & & & & $2.2 \times 10^{-3}$ & $<0 . i$ \\
\hline $\mathrm{Ar}-41$ & $9.8 \times 10^{-3}$ & & & & & & $9.8 \times 10^{-3}$ & 0.2 \\
\hline $\mathrm{Co}-60$ & & $2.9 \times 10^{-6}$ & & & & $2.7 \times 10^{-16}$ & $2.9 \times 10^{-6}$ & $<0.1$ \\
\hline $\mathrm{Zn}-65$ & & & & & & & & $<0.1$ \\
\hline $\mathrm{Kr}-85$ & $1.7 \times 10^{-5}$ & & & & & & $1.7 \times 10^{-5}$ & $<0.1$ \\
\hline Sr-90 & $4.5 \times 10^{-4}$ & $3.1 \times 10^{-3}$ & $4.2 \times 10^{-5}$ & $2.7 \times 10^{-5}$ & $5.7 \times 10^{-5}$ & $2.1 \times 10^{-4}$ & $3.9 \times 10^{-3}$ & $<0.1$ \\
\hline Zr-95 & & & & & & $5.0 \times 10^{-15}$ & $5.0 \times 10^{-15}$ & $<0.1$ \\
\hline $\mathrm{Nb}-95$ & & & & & & & & $<0.1$ \\
\hline Ru-106 & & $1.6 \times 10^{-6}$ & & & & $4.5 \times 10^{-12}$ & $1.6 \times 10^{-6}$ & $<0.1$ \\
\hline Sb-125 & & & & & & $6.1 \times 10^{-15}$ & $6.1 \times 10^{-15}$ & $<0.1$ \\
\hline I-129 & & $6.4 \times 10^{-2}$ & & & & & $6.4 \times 10^{-2}$ & 1.0 \\
\hline I-131 & $4.8 \times 10^{-7}$ & $1.4 \times 10^{-5}$ & & & $1.9 \times 10^{-5}$ & & $3.4 \times 10^{-5}$ & $<0.1$ \\
\hline I-133 & & & & & $3.3 \times 10^{-6}$ & & $3.3 \times 10^{-6}$ & $<0.1$ \\
\hline I-135 & & & & & $9.5 \times 10^{-5}$ & & $9.5 \times 10^{-5}$ & $<0.1$ \\
\hline $\mathrm{Xe}-135$ & & & & & $6.3 \times 10^{-8}$ & & $6.3 \times 10^{-8}$ & $<0.1$ \\
\hline Cs-134 & & $1.1 \times 10^{-7}$ & & & & $4.3 \times 10^{-17}$ & $1.2 \times 10^{-7}$ & $<0.1$ \\
\hline Cs-137 & $3.3 \times 10^{-4}$ & $2.4 \times 10^{-3}$ & & & $4.3 \times 10^{-5}$ & $4.7 \times 10^{-10}$ & $2.7 \times 10^{-3}$ & $<0.1$ \\
\hline Ce-141 & & & & & & & & $<0.1$ \\
\hline Ce-144 & & $3.8 \times 10^{-8}$ & & & & $3.7 \times 10^{-14}$ & $3.8 \times 10^{-8}$ & $<0.1$ \\
\hline Pm-147 & & & & & & & & $<0.1$ \\
\hline Eu-154 & & & & & & $2.4 \times 10^{-12}$ & $2.4 \times 10^{-12}$ & $<0.1$ \\
\hline Eu-155 & & & & & & $4.2 \times 10^{-14}$ & $4.2 \times 10^{-2}$ & $<0.1$ \\
\hline U-235 & & $8.6 \times 10^{-2}$ & $2.9 \times 10^{-4}$ & & & $3.2 \times 10^{-3}$ & $8.9 \times 10^{-2}$ & 1.4 \\
\hline Pu-238 & & $9.3 \times 10^{-2}$ & & & & $8.5 \times 10^{-4}$ & $9.4 \times 10^{-2}$ & 1.5 \\
\hline Pu-239 & $1.6 \times 10^{-6}$ & $1.6 \times 10^{-1}$ & $7.6 \times 10^{-4}$ & $1.2 \times 10^{-4}$ & $1.3 \times 10^{-2}$ & $1.2 \times 10^{-4}$ & $1.8 \times 10^{-1}$ & 2.7 \\
\hline Am-241 & & $2.7 \times 10^{-2}$ & & & $5.7 \times 10^{-6}$ & $2.1 \times 10^{-10}$ & $2.7 \times 10^{-2}$ & 0.4 \\
\hline $\mathrm{Cm}-244$ & & $2.9 \times 10^{-3}$ & & & $9.9 \times 10^{-6}$ & $9.2 \times 10^{-10}$ & $2.9 \times 10^{-3}$ & $<0.1$ \\
\hline Dose Total & $2.8 \times 10$ & $3.6 \times 10$ & $1.1 \times 10^{-3}$ & $2.9 \times 10^{-2}$ & $1.3 \times 10^{-2}$ & $4.9 \times 10^{-3}$ & $6.4 \times 10$ & \\
\hline$\%$ of Total & 43.3 & 55.9 & $<0.1$ & 0.4 & 0.2 & $<0.1$ & & \\
\hline
\end{tabular}


Table 9. Maximum Individual Dose ${ }^{a}$ Commitment at Plant Perimeter from Liquid Releases

BY PATHWAY

\begin{tabular}{lcc}
\multicolumn{1}{c}{ Pathway } & $\begin{array}{c}\text { Max. Individual } \\
\text { Dose (mrem) }\end{array}$ & $\begin{array}{c}\text { Percent of } \\
\text { Total Dose }\end{array}$ \\
\hline Fish Consumption & $5.6 \times 10^{-2}$ & 44.7 \\
Drinking Water & $5.0 \times 10^{-2}$ & 39.9 \\
Invertebrate Consumption & $1.9 \times 10^{-2}$ & 15.3 \\
Shoreline Activities & $1.6 \times 10^{-4}$ & 0.1 \\
Boating & $1.2 \times 10^{-7}$ & $<0.1$ \\
Swimming & $1.0 \times 10^{-7}$ & $<0.1$ \\
Total & $1.3 \times 10^{-1}$ & \\
BY RADIONUCLIDE & & \\
& Max. Individual & Percent of \\
Radionuclide & Dose (mrem) & Total Dose \\
\hline H-3 & $4.4 \times 10^{-2}$ & 35.1 \\
Sr-90 & $2.3 \times 10^{-2}$ & 18.1 \\
I-129 & $5.5 \times 10^{-4}$ & 0.4 \\
Cs-137 & $4.7 \times 10^{-2}$ & 37.3 \\
Pm-147 & $2.7 \times 10^{-7}$ & $<0.1$ \\
U-235,238 & $5.0 \times 10^{-5}$ & $<0.1$ \\
Pu-239 & $1.1 \times 10^{-2}$ & 8.8 \\
Total & $1.3 \times 10^{-1}$ & \\
\hline a. Hypothetical person just downstream of SRS. There are no known persons who meet the hypothetical situation. \\
$\quad$ Committed effective dose equivalent is presented.
\end{tabular}

Table 10. Population Dose ${ }^{\mathrm{a}}$ Commitment from Liquid Releases

\section{BY PATHWAY}

\begin{tabular}{lcc}
\multicolumn{1}{c}{ Pathway } & $\begin{array}{c}\text { Population Dose } \\
\text { (Person-rem) }\end{array}$ & $\begin{array}{c}\text { Percent of } \\
\text { Total Dose }\end{array}$ \\
\hline Beaufort-Jasper Water & $1.8 \times 10$ & 69.5 \\
Port Wentworth Water & $6.6 \times 10^{-1}$ & 26.2 \\
Fish Consumption* & $1.0 \times 10^{-1}$ & 4.1 \\
Recreation & $6.5 \times 10^{-3}$ & 0.2 \\
& $2.5 \times 10^{\circ}$ & \\
Total & & \\
BY RADIONUCLIDE & Population Dose & Percent of \\
& (Person-rem) & Total Dose \\
\hline H-3 Radionuclide & $2.0 \times 10$ & 79.3 \\
Sr-90 & $2.5 \times 10^{-1}$ & 9.9 \\
I-129 & $1.5 \times 10^{-2}$ & 0.6 \\
Cs-137 & $9.9 \times 10^{-2}$ & 3.9 \\
Pm-147 & $5.6 \times 10^{-7}$ & $<0.1$ \\
U-235,238 & $1.0 \times 10^{-3}$ & $<0.1$ \\
Pu-239 & $1.6 \times 10^{-1}$ & 6.4 \\
Total & $2.5 \times 10^{\circ}$ & \\
\hline
\end{tabular}

* includes sport and commercial fish and salt water vertetrates.

a. Committed effective dose equivalent. 
Figure 16. 10-Year History of Maximum Individual Dose from Liquid Releases

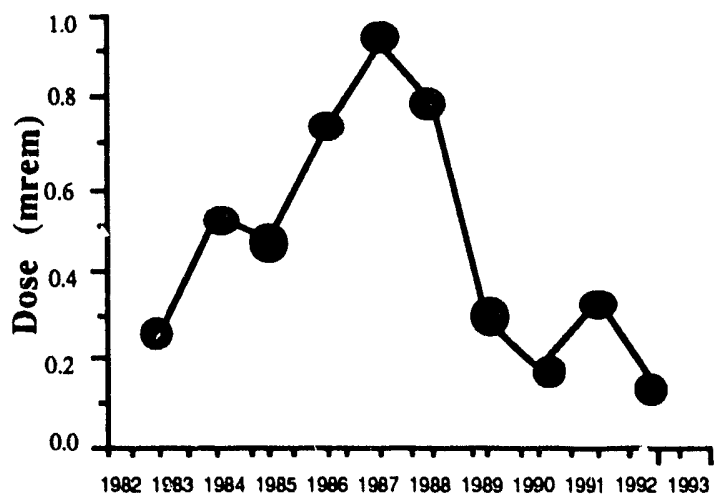

Year

\section{Dose Estimates}

Dose estimates for both atmospheric and liquid releases over the past five years are summarized in Table 13. The maximum individual at the SRS boundary (both atmospheric and liquid pathways) received a dose that was $30 \%$ less than in 1990 (data from 1991 are skewed and inappropriate for this comparison because of the K-Reactor aqueous tritium release). The total 50-mile and Savannah River user population dose resulting

Figure 17. 10-Year History of Population Doses to Savannah River Water Users

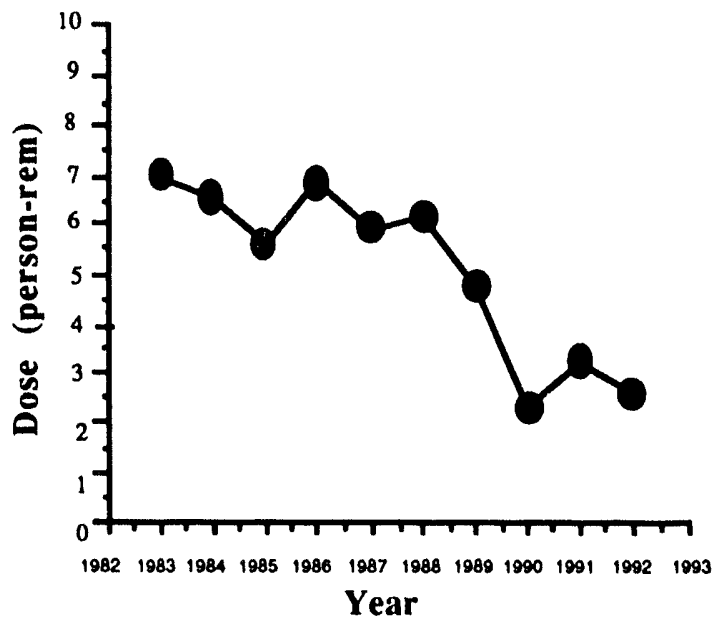

from atmospheric and liquid effluents is down, however, by about $21 \%$ from 1990 . The background doses to an average individual (about $300 \mathrm{mrem} / \mathrm{yr}$ ) and the 50-mile and drinking-water populations (approx. 200,000 person-rem/yr) from natural background are also given to show the relative impact of SRS operations on the surrounding environment. Maximum individual and population doses by, release mode and facility, are summarized in Table 14. 
Table 11. Maximum Individual Dose (mrem) from Liquid Releases

Nuclide Reactors Sepns Raw Mat. H. Water SRTC Misc Total \% of

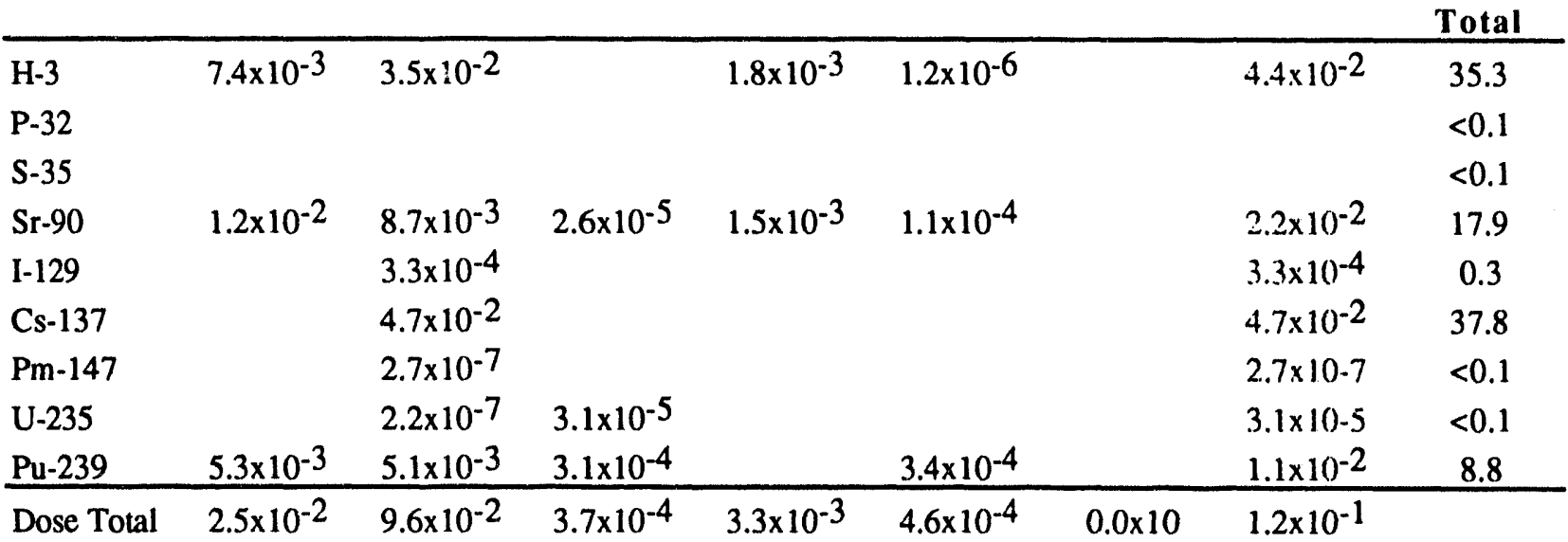

$\begin{array}{lllllll}\% \text { of Total } & 19.7 & 77.0 & 0.3 & 2.7 & 0.4 & <0.1\end{array}$

Table 12. Population Dose (person-rem) from Liquid Releases

Nuclide Reactors Sepns Raw Mat. H. Water SRTC Misc Total \% of

\begin{tabular}{|c|c|c|c|c|c|c|c|c|}
\hline & & & & & & & & Total \\
\hline $\mathrm{H}-3$ & $3.1 \times 10^{-1}$ & $1.5 \times 10$ & & $7.7 \times 10^{-2}$ & $5.0 \times 10^{-5}$ & & $1.9 \times 10$ & 73.9 \\
\hline P-32 & & & & & & & & $<0.1$ \\
\hline S-35 & & & & & & & & $<0.1$ \\
\hline Sr-90 & $7.4 \times 10^{-3}$ & $5.4 \times 10^{-3}$ & $1.6 \times 10^{-5}$ & $9.3 \times 10^{-4}$ & $6.9 \times 10^{-5}$ & & $1.4 \times 10^{-2}$ & 0.5 \\
\hline $1-129$ & & $4.7 \times 10^{-4}$ & & & & & $4.7 \times 10^{-4}$ & $<0.1$ \\
\hline Cs-137 & & $9.1 \times 10^{-2}$ & & & & & $9.1 \times 10^{-2}$ & 3.6 \\
\hline Pm-147 & & $2.9 \times 10^{-8}$ & & & & & $2.9 \times 10^{-8}$ & $<0.1$ \\
\hline U-235 & & $2.8 \times 10^{-8}$ & $4.1 \times 10^{-6}$ & & & & $4.1 \times 10^{-6}$ & $<0.1$ \\
\hline $\mathrm{Pu}-239$ & $2.7 \times 10^{-1}$ & $2.6 \times 10^{-1}$ & $1.6 \times 10^{-2}$ & & $1.7 \times 10^{-2}$ & & $5.6 \times 10^{-1}$ & 22.0 \\
\hline Dose Total & $5.9 \times 10^{-1}$ & $1.8 \times 10$ & $1.6 \times 10^{-2}$ & $7.8 \times 10^{-2}$ & $1.7 \times 10^{-2}$ & $0.0 \times 10$ & $2.5 \times 10$ & \\
\hline$\%$ of Total & 23.1 & 72.5 & 0.6 & 3.1 & 0.7 & $<0.1$ & & \\
\hline
\end{tabular}


Table 13. 1988 Through 1992 Adult Offsite Doses

1988

1989

1990

1991

$1992 \dagger$

Atmospheric Releases

Avg. Individual (mrem)

0.18

0.46

0.11

0.075

0.056

0.040

Max. Individual (mrem)*

21

0.31

0.16

0.14

0.10

50-Mile Population (per-rem)

17

9.6

7.1

6.4

Liquid Releases

Max. Individual (mrem)

0.79

0.30

0.17

0.34

0.13

Max. Ind. BJ (mrem)

0.13

0.12

0.061

0.081

0.070

Max. Ind. PW (mrem)

0.12

0.12

0.074

0.099

0.087

Population (person-rem) ${ }^{a}$

1.9

0.62

0.21

0.42

0.11

Beaufort-Jasper Pop (per-rem)

3.0

3.0

1.3

Total Population (per-rem)

Background (approximate dose)

6.2

1.2

1.5

2.1

1.8

0.56

$\underline{0.75}$

0.66

Individual

Population (685,000 persons) $b$

$300 \mathrm{mrem}$

200,000 person-rem

tbeginning in 1992, population data from the 1990 census used for population dose.

*beginning in 1991, maximum individual dose calculated assuming goat's milk consumption.

a. includes the consumption of sport and commercial fish, salt water invertebrates, and recreational activities on the Savannah River.

b. 1990 census, 50-mile population plus water consumers at Beaufort-Jasper and Port Wentworth.

Table 14. Summary of Maximum Individual and Population Dose for 1992

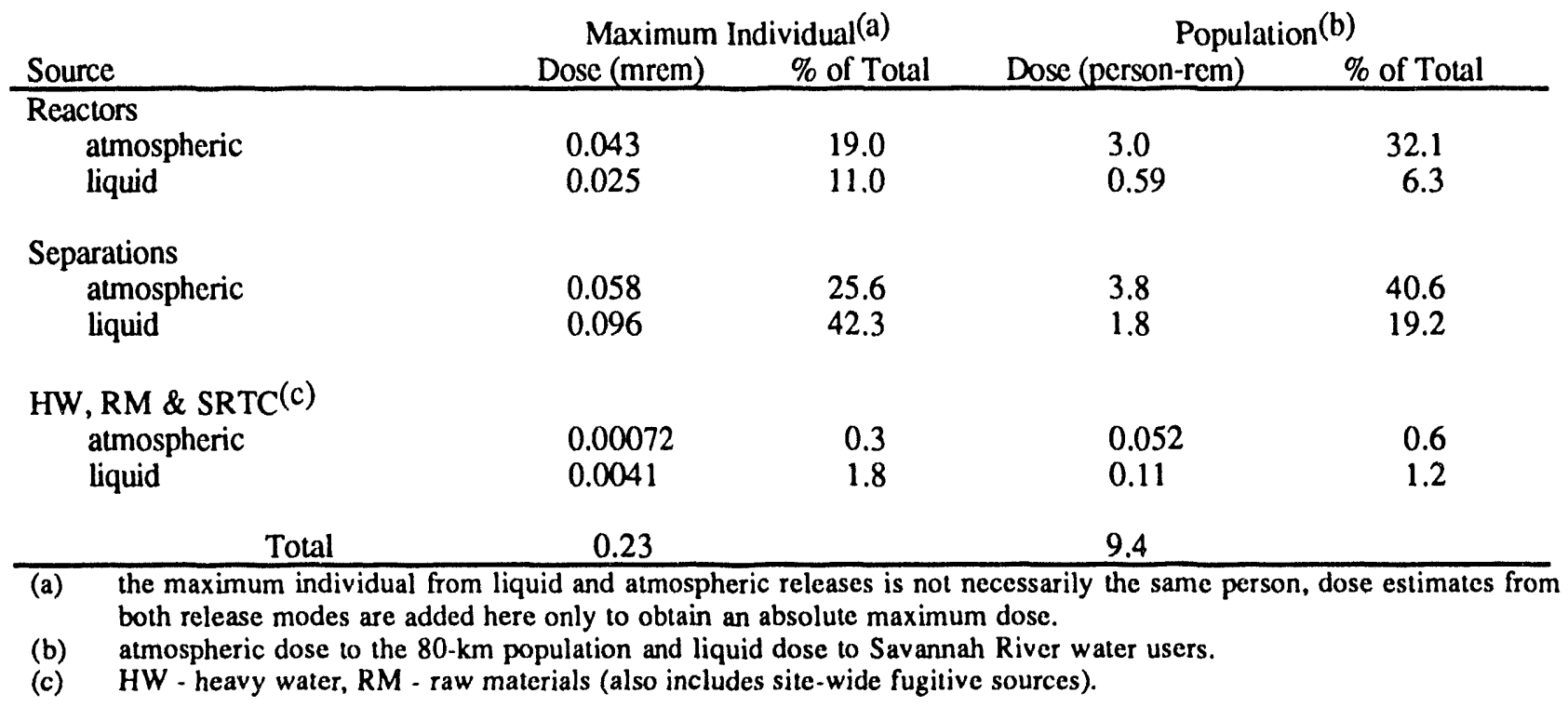



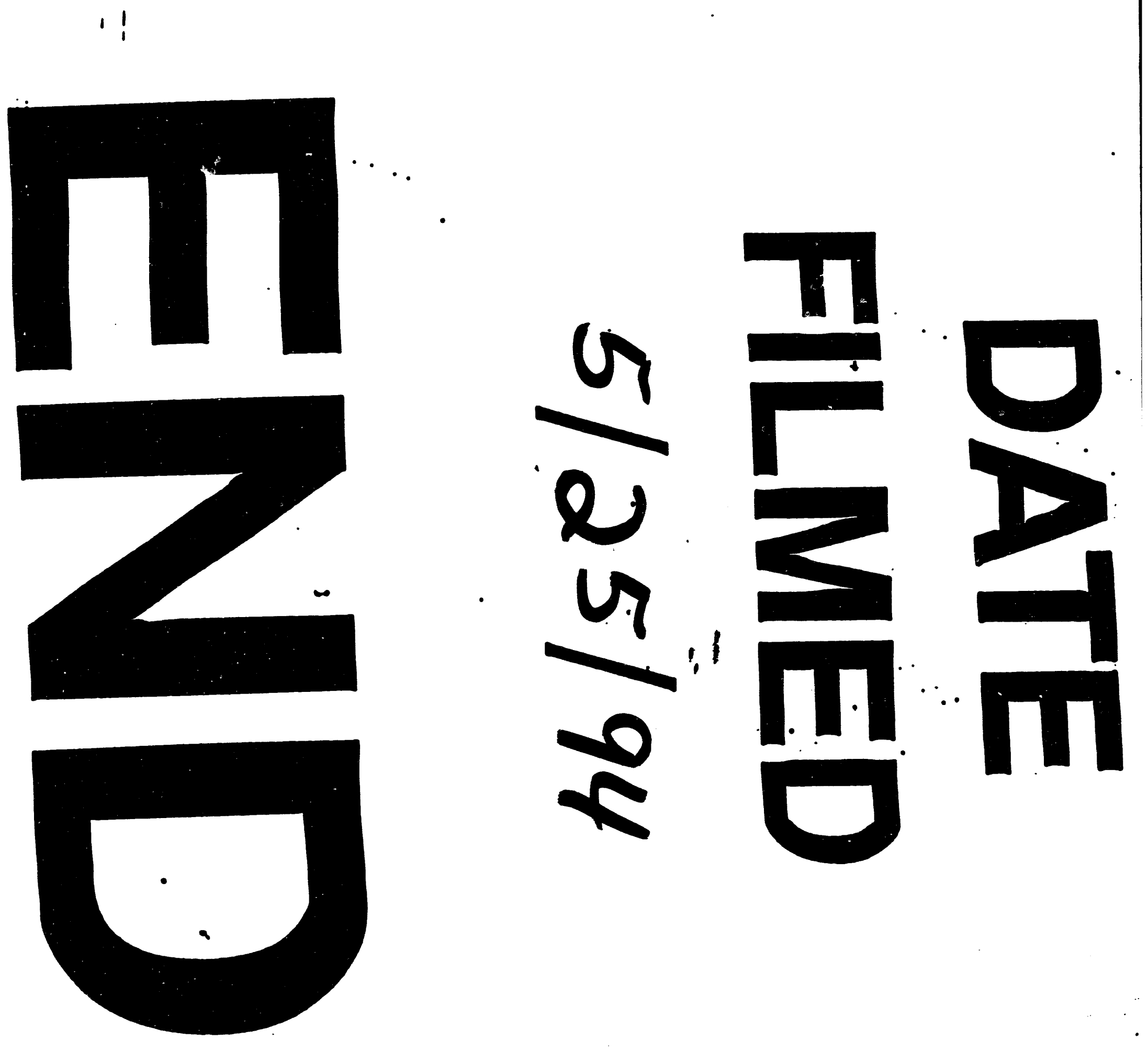
